\title{
Pengembangan Model Kampung Literasi untuk Meningkatkan Motivasi Pendidikan dan Minat Membaca Masyarakat Desa Kolam Kabupaten Deli Serdang
}

\section{Development of Literacy Village Model to Increase Education Motivation and Interest in Reading Community of Kolam Village in Deli Serdang Regency}

\author{
Sihar Pandapotan*, Sondang P. Pakpahan, Syahril \& Antonius Hendrick
}

Fakultas Keguruan Dan Ilmu Pendidikan, Universitas Terbuka, Indonesia

Diterima: 11 Maret 2020 ; Disetujui: 17 Maret 2020 ; Dipublish: 20 Maret 2020

*Corresponding Email: siharpandapotan@gmail.com

\begin{abstract}
Abstrak
Program Pengembangan Model Kampung Literasi Untuk Meningkatkan Motivasi Pendidikan Dan Minat Membaca Masyarakat ini dilaksanakan di Desa Kolam, Kecamatan Percut Sei Tuan, Kabupaten Deli Serdang, Provinsi Sumatera Utara. Desa Kolam telah menjadi mitra utama sejak program tahun 2017 dan didukung oleh mitra lainnya seperti Posyandu, Karang Taruna, sekolah-sekolah yang ada di Desa Kolam. Dengan membangun kemitraan yang luas, diharapkan selama tiga tahun program berjalan, Universitas Terbuka UPBJJ Medan akan mampu menjadikan Desa Kolam menjadi Kampung Literasi dimana masyarakatnya menjadi melek literasi dan pengetahuan, sehingga meningkatkan motivasi berpendidikan hingga perguruan tinggi. Dengan demikian pembangunan dan Pengembangan Sumberdaya manusia (SDM) di Desa Kolam akan meningkat dimasa depan. Program ini melanjutkan capaian program tahun 2017 dan 2018 yang lalu. Selama pelaksanaan PkM Nasional 2019 ini, berbagai kegiatan telah terlaksana, diantaranya adalah memberikan bantuan untuk renovasi ruang perpustakaan Desa Kolam, memberikan bantuan mobiler untuk perlengkapan perpustakaan Desa Kolam, dan memberikan bantuan rak-rak buku, membangun media informasi dan kampanye literasi, memfasiltasi penerbitan buku kumpulan cerita anak, dan peluncuran Desa Kolam Sebagai Kampung Literasi.
\end{abstract}

Kata Kunci: Program Pengembangan, Model Kampung Literasi, Motivasi Pendidikan, Minat Membaca

\begin{abstract}
The Village Literacy Model Development Program to Increase Motivation in Education and Community Reading Interest was carried out in Kolam Village, Percut Sei Tuan District, Deli Serdang Regency, North Sumatra Province. Pond Village has been a major partner since the 2017 program and is supported by other partners such as Posyandu, Karang Taruna, schools in Kolam Village. By building a broad partnership, it is hoped that during the three years the program runs, UPBJJ Open University in Medan will be able to turn the Village Pool into a Literacy Village where the community becomes literate and knowledge literate, thereby increasing the motivation of educating to tertiary institutions. Thus the development and development of human resources (HR) in the Village Pool will increase in the future. This program continues the program achievements in 2017 and 2018 ago. During the implementation of the 2019 National PkM, various activities have been carried out, including providing assistance for renovation of the Pool Village library space, providing mobile assistance for Pool Village library equipment, and providing bookshelves, building information media and literacy campaigns, facilitating book publishing a collection of children's stories, and the launch of the Village Pool as a Village of Literacy.

Keywords: Development Program, Village Literacy Model, Educational Motivation, Interest in Reading

How to cite: Pandapotan, S. Pakpahan, S.P. Syahril \& Hendrick, A. (2020). Pengembangan Model Kampung Literasi untuk Meningkatkan Motivasi Pendidikan dan Minat Membaca Masyarakat Desa Kolam Kabupaten Deli Serdang . Pelita Masyarakat: Jurnal Pengabdian Masyarakat 1(2): 110-126
\end{abstract}




\section{PENDAHULUAN}

Tujuan dari hasil pelaksanaan program Pengabdian masyarakat ini adalah terwujudnya Desa Kolam (desa dampingan Abdimas UT) menjadi Kampung Literasi yaitu desa yang masyarakatnya melek literasi, memiliki motivasi berpendidikan tinggi dan memiliki akses kepada buku dan sumber pengetahuan. Pelaksanaan program Pengabdian Kepada Masyarakat (PkM) Nasional-UT FKIP Tahun 2019 ini dilaksanakan sejak Bulan Agustus - Desember 2019. Program dilaksanakan di Desa Kolam, Kecamatan Percut Sei Tuan, Kabupaten Deli Serdang, Provinsi Sumatera Utara. Desa Kolam merupakan salah satu desa yang terletak di Kecamatan Percut Sei Tuan, kabupaten Deli Serdang.

Berikut kondisi tingkat pendidikan masyarakat di Desa Kolam menurut data tahun 2017 ; SD/MI: 4715 Orang; SLTP/MTs: 3063 Orang; SLTA/MA: 2399 Orang; S1/ Diploma: 416 Orang; Putus Sekolah: 502 Orang; Buta Huruf: 52 Orang. Jumlah Lembaga Pendidikan: Gedung TK/PAUD: 11 buah/Lokasi di Dusun; SD/MI: 5 buah/Lokasi di Dusun ; SLTP/MTs: 1 buah/Lokasi di Dusun; SLTA/MA: 0 buah/Lokasi di Dusun. Kondisi ini sangat membutuhkan dukungan pelaksanaan program PkM Nasional UT UPBJJ Medan Fakultas Keguruan dan Ilmu Pendidikan.

\section{ANALISIS SITUASI}

Desa Kolam adalah salah satu desa yang terletak di Kecamatan Percut Sei Tuan, Kabupaten Deli Serdang, Sumatera Utara. Mayoritas penduduknya berprofesi sebagai petani dan buruh. Sejak dari dahulu sampai sekarang, pekerjaan petani dan buruh merupakan pekerjaan turun temurun dan umumnya tidak banyak mengalami perubahan yang berarti. Masyarakat kelas pekerja atau penerima upah dari pemilik modal merupakan mayoritas, dan kalaupun mereka berusaha memiliki sendiri alat produksi, umumnya masih sangat konvensional, sehingga produktivitasnya kurang berkembang, kelompok inilah yang terus berhadapan dan digeluti oleh kemiskinan. Kondisi itu menyebabkan masyarakat Desa Kolam yang umumnya masih tergolong petani tradisional dan buruh-buruh dalam pekerjaan kasar dan tidak menetap, menyebabkan tingkat ekonomi desa cenderung stagnan. 
Sihar Pandapotan, Sondang P. Pakpahan, Syahril \& Antonius Hendrick, Pengembangan Model

Dengan demikian, masalah sosial budaya yang terdapat pada kehidupan masyarakat desa antara lain adalah: (a) rendahnya tingkat pendidikan, (b) miskin pengetahuan dan teknologi untuk menunjang pekerjaannya, (c) kurang tersedianya wadah pekerjaan informal

Melihat kondisi kehidupan masyarakat desa yang banyak mengalami kesulitan menyelesaikan anak sekolah formal karena keberadaan anak-mereka dimaksudkan untuk membantu ayahnya mencari nafkah. Pertanyaan mendasar adalah bagaimanakah model dukungan pendidikan bagi anak petani yang tinggal di pedesaan agar memiliki motivasi pendidikan dan minat kepada buku dan pengetahuan?. Pertanyaan ini muncul karena secara empirik anak-anak petani dan anak-anak pedesaan pada usia Sekolah Dasar (SD) dan Sekolah Mengah Pertama (SMP) angka putus sekolahnya cenderung tinggi, dan sebahagin merasa puas dengan hanya berpendidikan tingkat menegah pertama (SMP) dan menengah atas (SMA). Jika kondisi motivasi pendidikan sampai disini saja maka akan berpotensi untuk bekerja menjadi buruh atau pekerja kasar di mana mereka berada, dan ini sangat buruk untuk masa depan anak-anak dan masa depan Indonesia.

Kondisi di atas juga terjadi pada masyarakat Desa Kolam yang berpenduduk lebih dari 14.000 jiwa. Merasa cukup hanya berpendidikan SD, SMP atau paling tinggi tingkat SMA, rendah sekali minat untuk melanjutkan sampai tingkat perguruan tinggi. Oleh karena itu, Tim Pengabdian Kepada Masyarakat FKIP Universitas Terbuka bersama mitra Pemerintahan Desa Kolam Kecamatan Percut Sei Tuan, Kabupaten Deli Serdang, Sumatera Utara, sepakat selama tiga tahun mulai tahun 2017 hingga tahun 2019 akan menjadikan Desa Kolam sebagai Kampung Literasi dimana masyarakatnya menjadi melek literasi dan pengetahuan, sehingga meningkatkan minat baca dan motivasi berpendidikan hingga perguruan tinggi..

Pengabdian Kepada Masyarakat yang akan dilakukan Oleh Universitas Terbuka-FKIP adalah bentuk peran dan kontribusi Universitas untuk mendukung pembangunan masyarakat dengan menerapkan ilmu pengetahuan dan dukungan untuk meningkatkan motivasi pendidikan dengan meningkatkan minat membaca masyarakat sehingga mendukung peningkatan kualitas SDM dan motivasi untuk berpendidikan tinggi dalam masyarakat di lokasi program khususnya dan di wilayah Sumatera Utara umumnya. Program ini sesuai Program Kerja Sumatera Utara dimana pada tanggal 20 Mei 2017 Gubernur Sumatera Utara Ir. HT Erry Nuradi, M.Si mencanangkan provinsi Sumatera Utara sebagai provinsi literasi ke- 
4 yang telah mencanangkan selain Provinsi Riau, Nusa Tenggara Barat, dan DKI Jakarta (Harian WASPADA, 21 Mei 2017). Program kerja Sumatera Utara ini juga ditindaklanjuti oleh Pemerintahan Desa Kolam Kecamatan Percut Sei Tuan, Kabupaten Deli Serdang, Sumatera Utara.

\section{HASIL DAN PENCAPAIAN SETELAH PELAKSANAAN PKM UT TAHUN 2017 DAN 2018.}

Pada tahun 2017 dan 2018 PkM FKIP Universitas Terbuka telah berhasil mencapai beberapa kegiatan diantaranya adalah :

\begin{tabular}{|c|c|c|}
\hline No & Jenis Dan spesifikasi Luaran Kegiatan & Bukti \\
\hline 1 & $\begin{array}{l}\text { Pengembangan pusat belajar dan taman } \\
\text { bacaan masyarakat }\end{array}$ & $\begin{array}{l}\text { Berdirinya perpustakaan desa yang berpusat } \\
\text { di kantor Desa Kolam sebagai pusat taman } \\
\text { baca masyarakat. } \\
\text { Perpustakaan ini masih beroperasi secara } \\
\text { sederhana dan manual. }\end{array}$ \\
\hline 2 & $\begin{array}{l}\text { Pemberian bantuan buku } \\
\text { Pengembangan pusat belajar dan } \\
\text { bacaan masyarakat. }\end{array}$ & $\begin{array}{l}\text { Tersalurnya bantuan buku-buku untuk } \\
\text { koleksi perpustakaan desa } \\
\text { Saat ini tidak kurang dari 5oo buku yang ada } \\
\text { di perpsutakaan desa Kolam. }\end{array}$ \\
\hline 3 & $\begin{array}{l}\text { Pemberian bantuan alat dan kelengkapan } \\
\text { Taman Bacaan/perpustakaan }\end{array}$ & $\begin{array}{l}\text { Tersalurnya bantuan } 1 \text { unit laptop } \\
\text { Tersalurnya bantuan mobiler berupa lemari } \\
\text { buku, meja, kursi dan kelegkapan } \\
\text { perpustakaan desa }\end{array}$ \\
\hline 4 & $\begin{array}{l}\text { Pelatihan dasar pengelolaan pusat belajar dan } \\
\text { taman bacaan masyarakat }\end{array}$ & $\begin{array}{l}\text { Terlaksananya pelatihan pengelolaan program } \\
\text { literasi bagi pemuda dan guru. }\end{array}$ \\
\hline 5 & $\begin{array}{l}\text { Roadshow ke sekolah-sekolah dari tingkat SD- } \\
\text { SMP dengan memberikan ragam pelatihan } \\
\text { literasi. }\end{array}$ & Terlaksananya kegiatan literasi di 5 sekolah. \\
\hline 6 & $\begin{array}{l}\text { Pelaksanaan pelayanan belajar dan literasi ke } \\
\text { dusun-dusun untuk memotivasi tentang } \\
\text { pendidikan dan memberikan akses bahan } \\
\text { bacaan kepada masyarakat. }\end{array}$ & $\begin{array}{l}\text { Terlaksananya pelatihan literasi dan } \\
\text { kunjungan ke } 4 \text { dusun }\end{array}$ \\
\hline 7 & $\begin{array}{l}\text { Membangun manajemen perpustakaan } \\
\text { berbasis katalog digital dan berbais website. }\end{array}$ & $\begin{array}{l}\text { Saat ini perpustakaan desa Kolam dapat } \\
\text { diakses secara online } \\
\text { www.pustaka.padepokaniqro.com. }\end{array}$ \\
\hline 8 & $\begin{array}{l}\text { Memberikan bantuan sepeda Motor untuk si } \\
\text { MOLEK (Motor Literasi dan Edukasi). }\end{array}$ & $\begin{array}{l}\text { Beroprasinya Motor Literasi (si MOLEK) } \\
\text { untuk memmberikan layanan literasi kepada } \\
\text { siswa dan masyrakat di Desa Kolam dan } \\
\text { sekitarya. }\end{array}$ \\
\hline 9 & 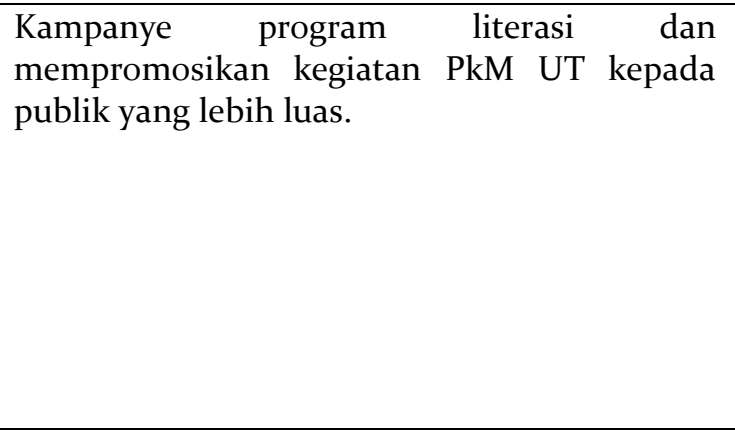 & $\begin{array}{l}\text { Pameran Hari Aksara Internasional Tingkat } \\
\text { Nasional sekaligus Festival Literasi Indonesia } \\
\text { yang dilaksanakan oleh Kementerian } \\
\text { Pendidikan dan kebudayaan Republik } \\
\text { Indonesia di Lubuk Pakam, Kabuaten Deli } \\
\text { Serdang, pada September 2018. } \\
\text { Pameran Gebyar Buku Oleh Dinas } \\
\text { Perpustakaa dan Arsip Provinsi Sumatera } \\
\text { Utara, di pelataran kantor Dinas } \\
\text { PerpustakaanProvinsi Sumatera Utara Medan. }\end{array}$ \\
\hline
\end{tabular}

Dari pencapaian diatas setidaknya saat ini tercipta beberapa kondisi : 
Sihar Pandapotan, Sondang P. Pakpahan, Syahril \& Antonius Hendrick, Pengembangan Model

- Perpustakaan Desa Kolam telah beroperasi, perpustakaan Desa Kolam dan diberi nama Padepokan Iqro.

- Mendapat apresiasi sebagai Perpustakan Desa Terbaik tingkat Sumatera Utara dari Dinas Arsip dan perustakaan Daerah Provisinsi Sumatera Utara.

- Perpusdes - Padepokan Iqro terpilih salah satu perpusdes percontohan dalam program Transformasi Perpustakaan Desa dari Perpustakaan Nasional Jakarta.

- Meningkatnya kapasitas masyarakat, khususnya kaum ibu/perempuan tentang teknik membaca (termasuk membaca nyaring) sehingga mereka mampu menerapkannya di rumah bersama anak-anak mereka.

- Barjalannya ragam program literasi di Padepokan Iqro, diantaranya adalah; kelas menulis untuk siswa SD dan SMP. Kelas Literasi keluarga, dan literasi berbasis inklusi sosial lainya.

- Kepala Desa Kolam mendapat penghargaan sebagai Kepala Desa inspiratif dari Bupati Deli Serdang, karena mengembangkan program perpustakaan desa- padepokan iqro.

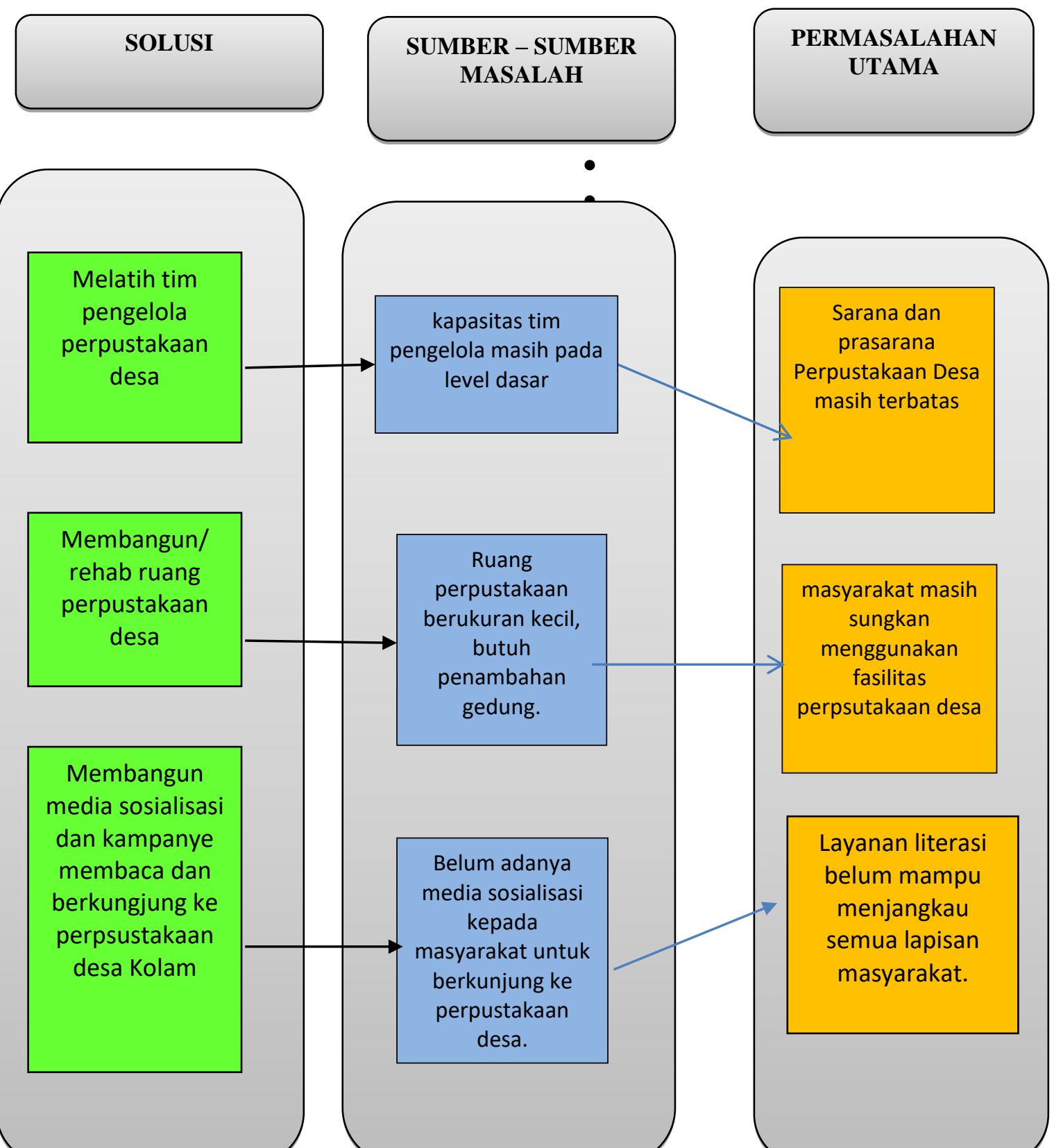


Diagram 1. Pohon Masalah (Keterangan; dibaca dari kanan ke kiri).

\section{HASIL PROGRAM PkM Nasional UT UPBJJ MEDAN TAHUN 2019}

Selama pelaksanaan Program Pengembangan Model Kampung Literasi Untuk Meningkatkan Motivasi Pendidikan Dan Minat Membaca Masyarakat Desa Kolam Kab. Deli Serdang, tahap ketiga tahun 2019 ini telah berhasil dilaksanakan beberapa kegiatan dan hasil sebagai berikut:

1. Bantuan rehab gedung dan penataan ruang perpustakaan Desa Kolan-Padepokan Iqro.

Pada tahap awal pelaksanaan program PkM UT tahun 2019 ini, Tim PkM Nasional UT Medan Fakultas KIP bersama pemerintahan Desa Kolam melakukan review pengembangan pengelolaan perpustakaan desa yang telah dibangun sejak tahun 2017 lalu.

Beberapa kegiatan yang dilakukan adalah :

- Bantuan rehab gedung dan ruang perpustakaan Desa Kolam. Tujuan dari bantuan rehab gedung ini adalah untuk membangun ruang khusus perpustakaan yang berisi koleksi buku-buku perpustakaan Desa Kolam-Padepokan Iqro, karena pada sebelumnya ruang perpustakaan dan ruang kantor bergabung pada ruang yang berukuran kecil, sementara pertambahan koleksi buku-buku terus bertambah sehingga membutuhkan ruang khusus perpustakaan.

- Melakukan penataan ruang perpustakaan dengan susunan yang rapi sesuai dengan kategori buku.

- Bantuan rehab gedung ini adalah perubahan kegiatan PkM nasional tahun 2019. Rencana awal adalah membangun pojok-pojok baca di beberapa dusun yang ada di Desa Kolam, tetapi rencana awal itu dirancang sebelum adanya bangunan perpustakaan desa secara mandiri terpisah dari gedung kantor pemerintahan desa. Karena Perpustakaan Desa Kolam sudah memiliki lahan dan gedung sendiri, maka PkM Nasional UT tahun 2019 mengubah kegiatan dengan mendukung optimalisasi pengelolaan perpustakaan Desa Kolam dengan memberikan bantuan rehab ruang 
khusus perpustakaan yang menjadi pusat penyimpanan koleksi buku-buku dan bahan bacaan.
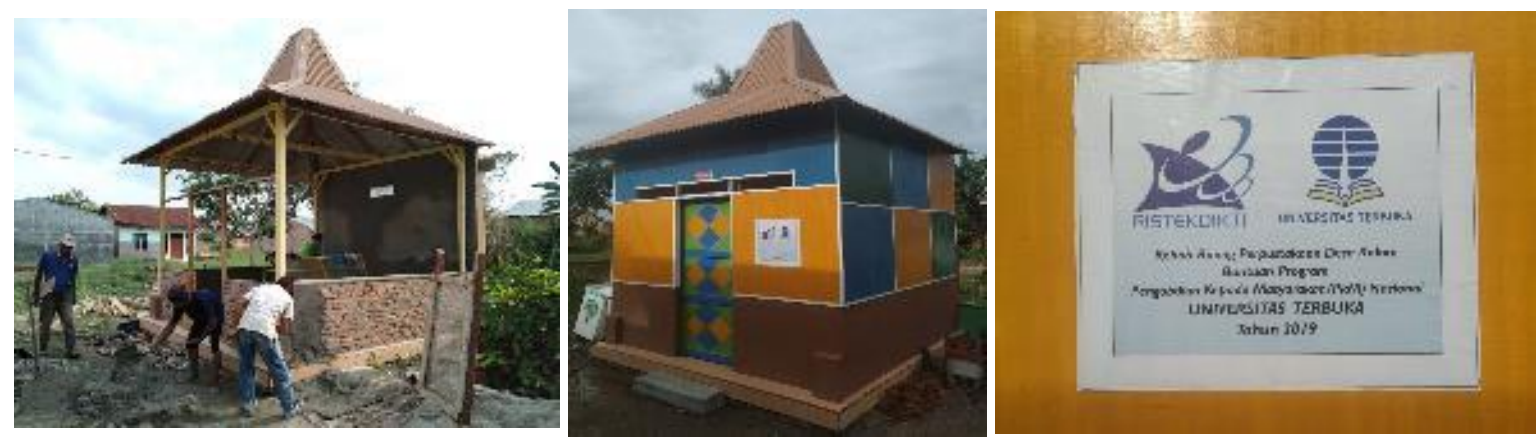

Gambar 1.

Proses pembangunan dan hasil rehab gedung perpustakaan Desa Kolam-Padepokan Iqro.

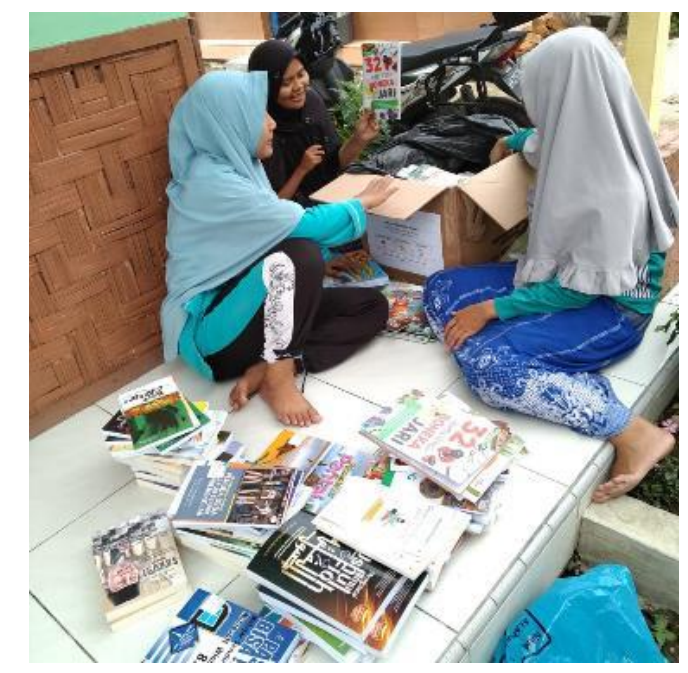

Gambar 2.

Aktivitas pengelompokan buku dan Penataan koleksi buku-buku perpustakaan Desa Kolam di dalam ruang baru bantuan PkM Nasional UT Medan tahun 2019.

2. Memberikan bantuan fasilitas pembuatan rak-rak buku dan fasilitas mobiler lainnya.

Dalam rangka mewujudkan perpustakaan Desa Kolam menjadi perpustakaan desa yang baik maka PkM Nasional UT Medan FKIP tahun 2019 memberikan bantuan beberapa fasilitas yaitu;

- Membuat rak (lemari) buku di ruang perpustakaan yang baru dibangun oleh program pkM UT 2019. Rak (lemari) buku ini juga dibuat dengan bentuk menyesuaikan dengan kondisi ruangan dan bentuk yang menarik. Bukan saja rak buku berbentuk kotak (standar) tetapi rak buku yang dibangun oleh bantuan PkM UT 2019 ini juga berbentuk limas dan rak vertical. 
- Memberikan bantuan mobiler berupa fasilitas meja dan kursi untuk melengkapai kebutuhan perpustakaan Desa Kolam.
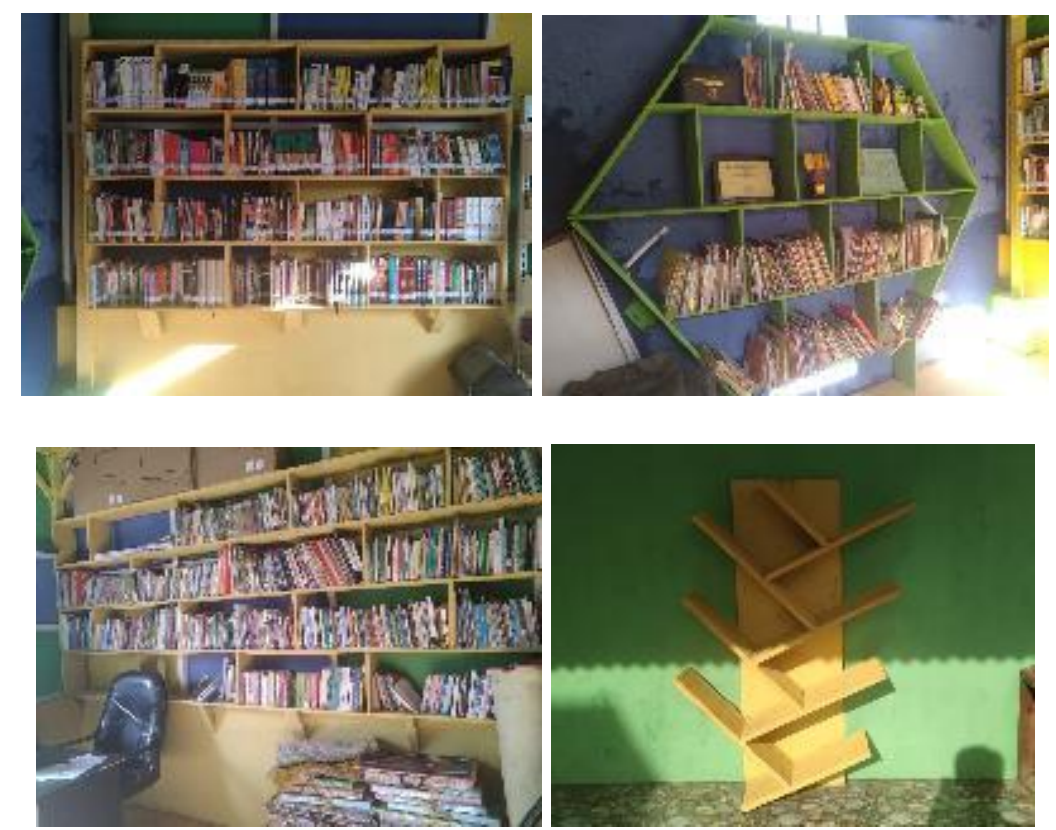

Gambar 3.

Rak-rak buku bantuan PkM Nasional UT tahun 2019 di perpustakaan-Padepokan Iqro Desa Kolam.

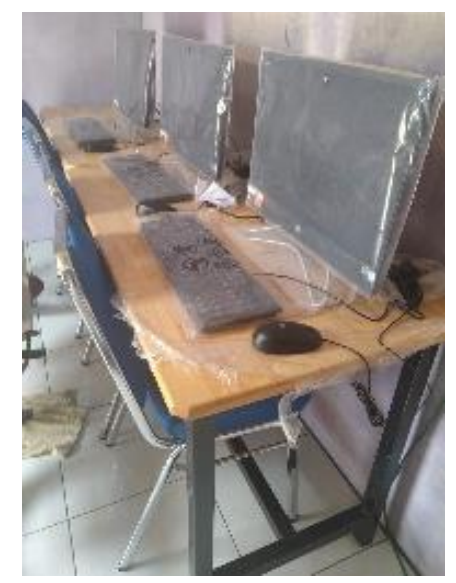

Gambar 4.

Bantuan berupa meja dan kursi dari PkM Nasional UT Medan tahun 2019 di perpustakaan-Padepokan Iqro Desa Kolam yang dipergunakan untuk meja dan kursi ruang belajar komputer. 


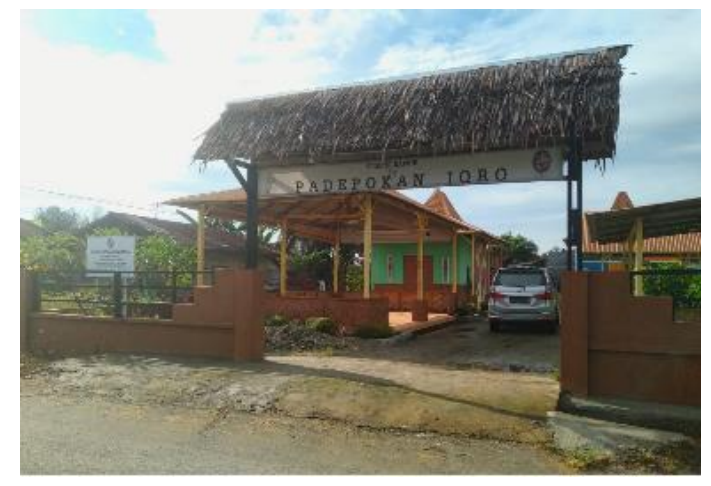

Gambar 5.

Tampilan baru Perpustakaan Desa Kolam yang semakin menarik dan banyak fasilitas di dalamnya menarik minat warga untuk berkujung.

3. Membangun Papan Media sosialisasi dan kampanye Literasi .

Bantuan pembangunan Papan Informasi dan sosilaisasi berjumlah 2 (dua) buah yang dipasang disepadan jalan utama Desa Kolam. Papan Informasi ini dibangun dengan tujuan untuk :

- Memberikan informasi kepada warga Desa Kolam bahwa Perpustakaan -Padepokan Iqro sudah beroperasi dan bisa diakses oleh semua warga Desa Kolam.

- Sebagai media promosi pelaksanaan Program PkM Nasional UT di Desa Kolam yang telah berjalan sejak tahun 2017 hingga 2019.

- Sebagai media kampanye kepada seluruh warga Desa Kolam agar meningkatkan daya literasi dan budaya baca keseluruh lapisan masyarakat desa.

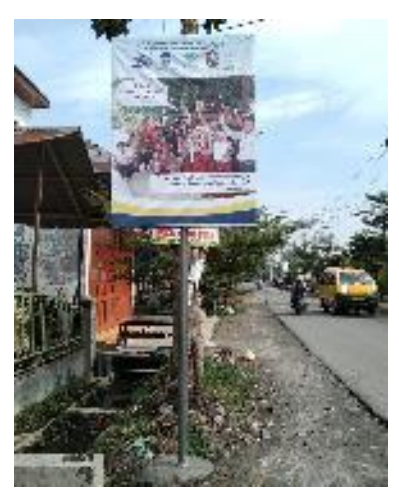

Gambar 6.

Papan Informasi dan sosialiasi program kampung Literasi yang dibangun dan dipasang di sepadan jalan utama Desa Kolam.

4. Layanan buku dan membaca di perpustakaan-Padepokan Iqro Desa Kolam yang didukung oleh program PkM Nasional UT Tahun 2019. 
Setelah memberikan beberapa dukungan fasilitas dan peralatan, maka PkM Nasional UT Tahun 2019 juga mendukung kegiatan layanan literasi yang berjalan di perpustakaan Desa Kolam:

- Mulai awal program PkM Nasional UT Medan tahun 2017 sudah memberikan bantuan buku-buku sebagai bahan bacaan dan koleksi di perpustakaan Desa Kolam, dan diteruskan untuk dipergunakan hingga tahun 2019. Maka dengan itu ditahun 2019 ini semua bantuan buku-buku tersebut dioptimalkan dalam kegiatan layanan literasi di perpustakaan Desa Kolam.

- Hingga Oktober 2019 layanan membaca dan peminjaman buku terus berjalan dan terus meningkat. Capaian positif ini dibuktikan dengan daftar kunjungan anak-anak, warga dan tamu yang datang berkunjung ke padepokan Iqro.

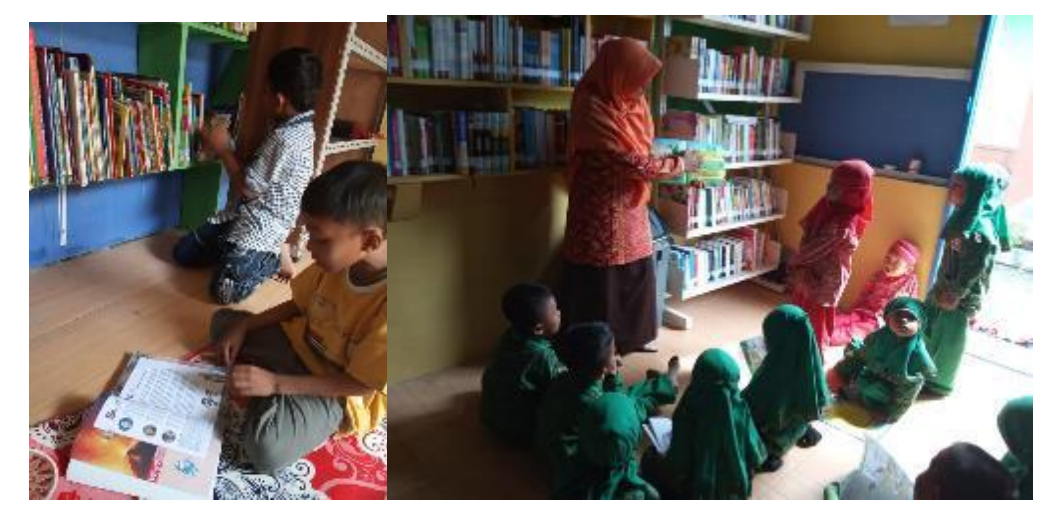

Gambar 7.

Kegiatan membaca dan peminjaman buku yang berjalan di perpustakaan Desa Kolam.

5. Membuka kelas menulis sebagai kegiatan literasi baca tulis.

Kelas menulis merupakan kegiatan yang dirancang untuk menguatkan literasi baca tulis khususnya kepada pelajar sekolah dasar (SD) dan sekolah menengah (SMP). Kelas menulis dibuka selama 2 kali dalam seminggu, yaitu pada setiap hari kamis dan jumat pukul 14.00 sampai dengan 17.00 WIB. Kelas menulis dilaksananakan selama tiga bulan mulai Oktober hingga Desember 2019. Kelas menulis diikuti oleh 30 peserta dari tingkat SD dan SMP yang ada di Desa Kolam.

Tujuan kegiatan kelas menulis adalah ;

- Meningkatkan kemampuan membaca ragam referensi dan mampu menuliskan kembali dengan Bahasa pemahamaman masing-masing anak. 
Sihar Pandapotan, Sondang P. Pakpahan, Syahril \& Antonius Hendrick, Pengembangan Model

- Meningkatkan kemampuan menulis tingkat dasar dalam bentuk cerita singkat dan puisi.

- Meningkatkan daya kreativitas dan imajinasi anak.

- Memfasilitasi ruang karya sastra bagi anak

- Mendorong bakat menulis pada anak.

- Memfasilitasi penerbitan buku karya anak-anak kelas menulis.

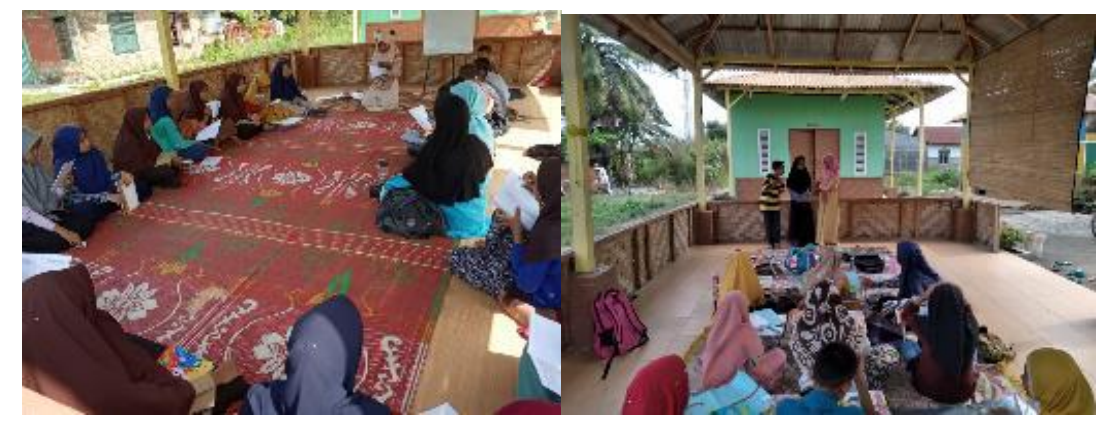

Gambar 8 .

Kegiatan kelas menulis yang dilaksanakan selama 3 bulan dan membina peserta sebanyak 30 anak-anak tingkat SD dan SMP.

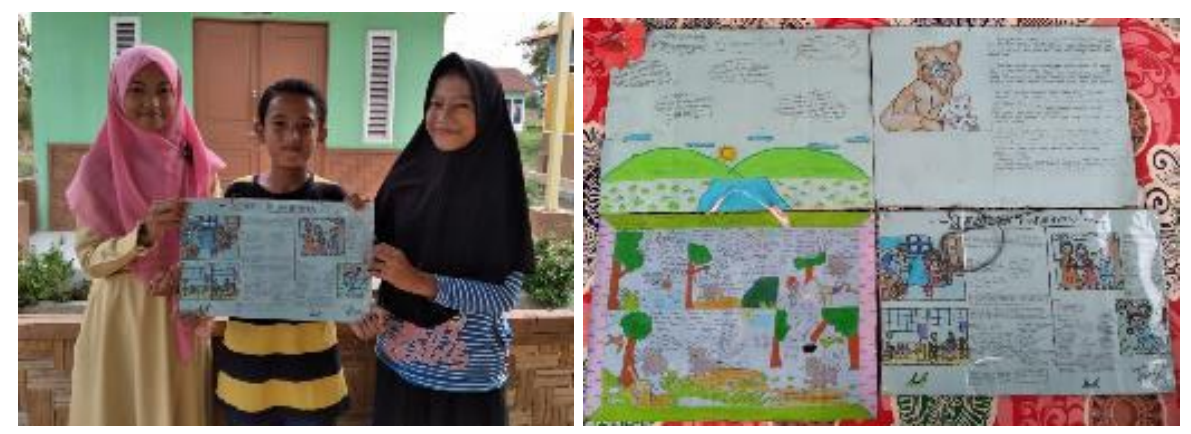

Gambar 9. Hasil karya tulisan berupa cerita bergambar dari anak-anak peserta kelas menulis.

Diakhir program PkM 2019, FKIP dapat memfasilitasi penerbitan buku-buku karya anak-anak kelas menulis berupa buku Kumpulan Cerita Anak sebanyak 100 eksamplar.

6. Peluncuran Desa Kolam sebagai Kampung Literasi.

Kegiatan terakhir pada program PkM Nasional FKIP-UT Medan di Desa Kolam adalah menetapkan dan meluncurkan Desa Kolam sebagai Kampung Literasi. Peluncuran ini dihadiri oleh Plt Kepala Dinas Perpustakaan dan Arsip Deli Serdang, Drs. Misran Sihaloho, M.Si. Kepala Unit Program Belajar Jarak Jauh (UPBJJ) Universitas Terbuka, Ibu Dra.Sondang Purnamasari Pakpahan, M.A., Kepala Desa Kolam, Bapak Jupri Purwanto, Pengelola Perpustakaan Padepokan Iqra, Babinsa, Duta Pendidikan Sumatera Utara, 
Tokoh Masyarakat dan warga Desa Kolam. Anak-anak di Padepokan Iqra juga turut menampilkan kreativitas seperti tari tradisional, pembacaan puisi, pantomim dan membaca dongeng.

Peluncuran Desa Kolam sebagai Kampung Literasi merupakan hasil yang nyata dari pelaksanaan PkM Nasional FKIP-UT Medan, yang mendapat apresiasi dari Dinas Perpustakaan dan Arip kabupaten Deli Serdang. Dengan diluncurkannya sebagai Kampung Literasi, maka Desa Kolam menjadi yang pertama di Kabupaten Deli Serdang yang berpredikat sebagai Kampung Literasi. Predikat ini sangat layak diberikan kepada Desa Kolam karena setelah pelaksanaan PkM Nasional tahun 2019, FKIP UT Medan mampu memfasilitasi Desa Kolam dengan berbagai fasilitas Literasi diantaranya yaitu;

- Ruang perpustakaan dan koleksi buku yang beragam.

- Memiliki moda transportasi berupa motor literasi.

- Padepokan Iqro telah menjadi pusat diskusi warga

- Padepokan Iqro menjadi pusat belajar dan pelatihan warga Desa Kolam.

- Rutinnya kegiatan belajar dan kegiatan literasi di Padepokan Iqro.

- Adanya media literasi publik yang dipasang di beberapa dusun.

- Peluncuran Desa Kolam Sebagai Kampung Literasi.

- Peluncuran dan Bedah Buku.
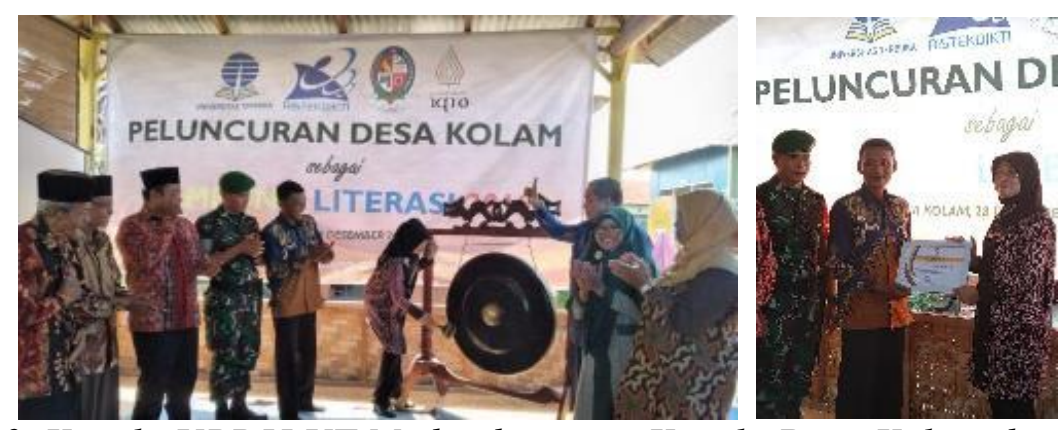

Gambar 10. Kepala UPBJJ UT Medan bersama Kepala Desa Kolam dan para mitra meresmikan Desa Kolam Sebagai Kampung Literasi tahun 2019. 
Sihar Pandapotan, Sondang P. Pakpahan, Syahril \& Antonius Hendrick, Pengembangan Model

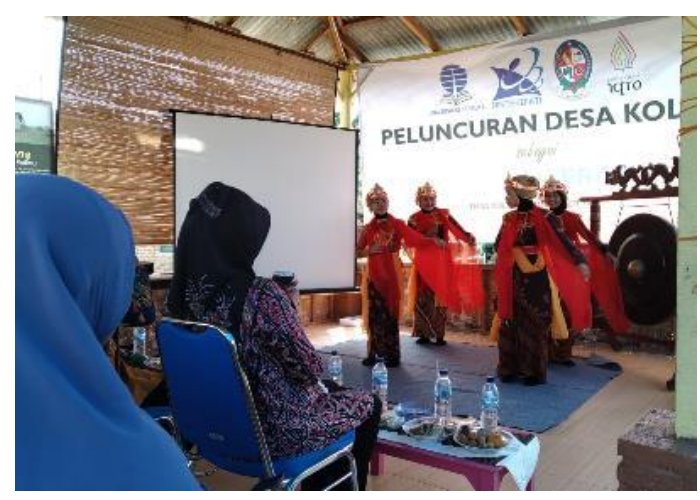

Gambar 11. Penampilan Tari daerah dari anak-anak binaan Padepokan Iqro saat acara peluncuran Kampung Literasi tahun 2019.

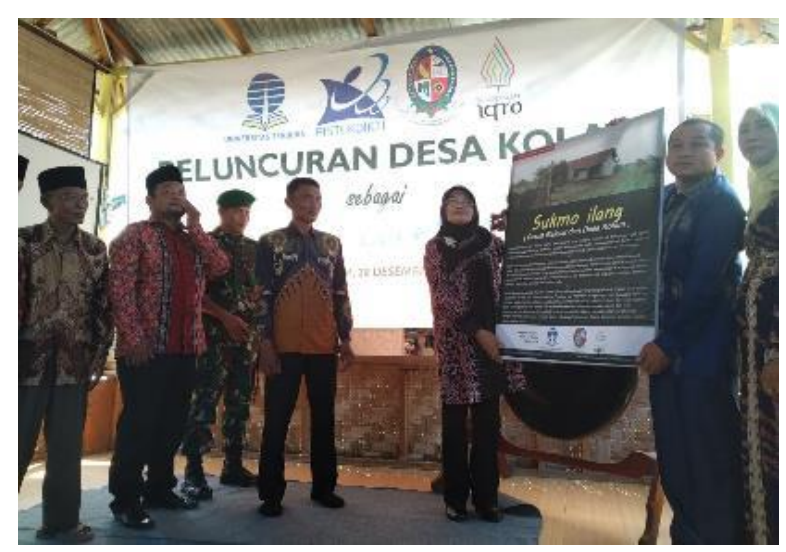

Gambar 12. Simbolis penyerahan Media Literasi tentang Cerita rakyat yang ada di Desa Kolam saat acara peluncuran Kampung Literasi tahun 2019.

7. Publikasi Media tentang program PkM FKIP UT Medan tahun 2019.

Diakhir program PkM tahun 2019, tim mempublikasikan peluncuran Desa Kolam sebagai Kampung Literasi ke media Televisi dan media online/cetak. Capaian menjadi Kampung Literasi merupakan capaian baik dan dampak yang nyata dirasakan oleh warga Desa Kolam setelah pelaksanaan PkM 2019.

Tujuan dari publikasi media ini adalah untuk menginformasikan secara luas kepada khalayak di Sumatera Utara khususnya dan di Indonesia secara umum, bahwa Universitas Terbuka berkomitmen untuk mendukung pembangunan melalui program PkM di Desa Kolam. 


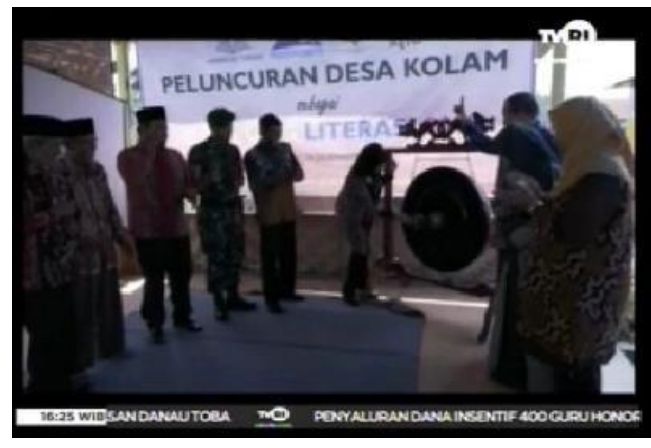

Gambar 13. Cuplikan tayangan di media TVRI Medan saat acara peluncuran Kampung Literasi tahun 2019.

Berikut adalah link berita tentang program PkM FKIP UT tahun 2019 ;

- https://medan.tribunnews.com/2019/12/28/desa-kolam-diperkenalkan-sebagai-kampungliterasi-di-deliserdang

- https://medan.tribunnews.com/2019/12/28/desa-kolam-di-percut-seituan-jadi-kampung$\underline{\text { literasi }}$

\section{HASIL YANG TELAH DICAPAI}

Selama periode awal PkM UT 2019 dengan Program Pengembangan Model Kampung Literasi Untuk Meningkatkan Motivasi Pendidikan Dan Minat Membaca Masyarakat Desa Kolam Kab. Deli Serdang, capaian dan hasil yang yang telah ada adalah sebagai berikut :

Tabel. Keluaran kegiatan PkM FKIP UT Medan tahun 2019.

\begin{tabular}{|l|l|l|}
\hline No & Jenis Dan spesifikasi Luaran Kegiatan & Bukti \\
\hline $\mathbf{1}$ & $\begin{array}{l}\text { Memberikan bantuan rehab gedung } \\
\text { perpustakaan dan penataan ruang perpustakaan } \\
\text { Desa Kolam agar lebih lengkap dan rapi untuk } \\
\text { memaksimalkan program dan layanan literasi. }\end{array}$ & $\begin{array}{l}\text { Terbangunnya 1 gedung/ruang khusus } \\
\text { perpustakaan Desa Kolam. } \\
\text { Buku-buku tertata rapi di ruang perpustakaan } \\
\text { Desa Kolam. }\end{array}$ \\
\hline $\mathbf{2}$ & $\begin{array}{l}\text { Memberi bantuan mobiler berupa meja, kursi, } \\
\text { dan rak buku. }\end{array}$ & $\begin{array}{l}\text { Tersedianya meja, kursi yang melengkapi } \\
\text { ruang komputer dan mengoptimalkan } \\
\text { layanan belajar komputer di Perpustakaan } \\
\text { Desa Kolam. } \\
\text { Bertambahnya 5 unit rak buku di ruang } \\
\text { perpustakaan Desa Kolam. }\end{array}$ \\
\hline 3 & $\begin{array}{l}\text { Bantuan pembangunan Papan promosi dan } \\
\text { sosialisasi program }\end{array}$ & $\begin{array}{l}\text { Terbangunnya 2 unit papan informasi dan } \\
\text { sosialisasi program PkM Nasional UT Medan } \\
\text { di Desa Kolam. } \\
\text { Terpasangnya 2 unit papan informasi dan } \\
\text { sosialisasi literasi di sepadan jalan utama Desa } \\
\text { Kolam sebagai media mengajak warga untuk } \\
\text { meningkatkan budaya baca dan berkunjung } \\
\text { ke perpustakaan Desa Kolam. }\end{array}$ \\
\hline
\end{tabular}


Sihar Pandapotan, Sondang P. Pakpahan, Syahril \& Antonius Hendrick, Pengembangan Model

\begin{tabular}{|c|c|c|}
\hline 4 & $\begin{array}{l}\text { Pelatihan literasi keluarga melalui pelatihan } \\
\text { teknik membaca nyaring "Reading Aloud" dan } \\
\text { pelatihan parenting }\end{array}$ & $\begin{array}{l}\text { Terlaksananya } 2 \text { kali pelatihan teknik } \\
\text { membaca nyaring untuk kaum ibu. } \\
\text { Terlaksananya } 1 \text { kali sesi parenting untuk } \\
\text { kaum ibu. }\end{array}$ \\
\hline 5 & $\begin{array}{l}\text { Perpustakaan Desa Kolam mendapat apresiasi } \\
\text { dari Dinas Perpustakaan dan Arsip Daerah } \\
\text { Provinsi Sumatera Utara }\end{array}$ & $\begin{array}{l}\text { Terpilih sebagai juara } 1 \text { perpustakaan desa } \\
\text { terbaik tingkat Sumatera Utara. }\end{array}$ \\
\hline 6 & $\begin{array}{l}\text { Mendapat apresiasi dari Perpustakaan Nasional } \\
\text { Republik Indonesia }\end{array}$ & $\begin{array}{l}\text { Dipilih menjadi salah satu percontohan } \\
\text { perpustakaan desa dalam program } \\
\text { Transformasi perpustakaan berbasis inklusi } \\
\text { sosial. } \\
\text { Mendapat bantuan } 3 \text { unit komputer } \\
\text { Mendapat bantuan 1ooo eksamplar buku. }\end{array}$ \\
\hline 7 & $\begin{array}{l}\text { Peluncuran Desa Kolam sebagai kampung } \\
\text { Literasi }\end{array}$ & $\begin{array}{l}\text { Desa Kolam menjadi Kampung Literasi yang } \\
\text { pertama di Kabupaten Deli Serdang } \\
\text { Acara peluncuran Kampung Literasi } \\
\text { mendapat dukungan dari Dinas Perpustakaan } \\
\text { dan Arsip kab.Deli Serdang. }\end{array}$ \\
\hline 8 & Terbitnya buku kumpulan cerita anak & $\begin{array}{l}\text { Tercetaknya sebanyak 10o eksamplar buku } \\
\text { kumpulan cerita anak hasil karya peserta } \\
\text { kelas menulis. } \\
\text { Buku ini sebagai bukti karya literasi anak- } \\
\text { anak Desa Kolam. }\end{array}$ \\
\hline 9 & Adanya media literasi desa & $\begin{array}{l}\text { Terpasangnya } 3 \text { unit media literasi desa yang } \\
\text { berisi tentang potensi desa dan cerita rakyat } \\
\text { asli Desa Kolam. } \\
\text { Media literasi ini sebagai media informasi dan } \\
\text { pengetahuan publik tentang potensi Desa } \\
\text { Kolam. }\end{array}$ \\
\hline 10 & $\begin{array}{l}\text { Publikasi media tentang hasil program PkM } \\
\text { FKIP UT Medan }\end{array}$ & $\begin{array}{l}\text { Liputan TVRI Medan tentang peluncuran } \\
\text { Desa Kolam sebagai kampung Literasi } \\
\text { Beberapa berita di media cetak dan dam } \\
\text { media online. } \\
\text { Peluncuran dan Bedah Buku. }\end{array}$ \\
\hline
\end{tabular}

Pelaksanaan PkM Nasional FKIP UT Medan tahun 2019 ini membawa dampak yang sangat baik bagi waga Desa Kolam. Selain capaian dan hasil kegiatan yang telah dijelaskan pada tabel sebelumnya. Beberapa impact program PkM ini adalah sebagai berikut ;

- Desa Kolam semakin dikenal oleh pemerintahan Kabupaten dan Kecamatan karena kreatif membangun SDM warganya melalui pengembangan Literasi bersama Universitas Terbuka Medan.

- Perpustakaan desa kolam saat ini telah menjadi pusat berbagai kegiatan warga, seperti kegiatan seminar, diskusi warga, dan pusat pelatihan masyarakat.

- Perpustakaan Desa Kolam Padepokan Iqro menjadi Juara-1 dan predikat perpustakaan desa terbaik dari Dinas Perpustakaan dan Arsip Provinsi Sumatera Utara. 
- Pengelola Perpustakaan Desa Kolam selalu menjadi referensi pengembangan Perpustakaan Desa di tingkat Provinsi Sumatera Utara.

- Pengelola Perpustakaan Desa Kolam telah diundang ke berbagai seminar dan pelatihan di tingkat Sumatera Utara dan nasional.

- Pengelola perpustakaan Desa Kolam berhasil membangun jaringan kerjasama antara perpustakaan Desa Kolam (Padepokan Iqro) dengan Universitas lain dan pihak swasta.

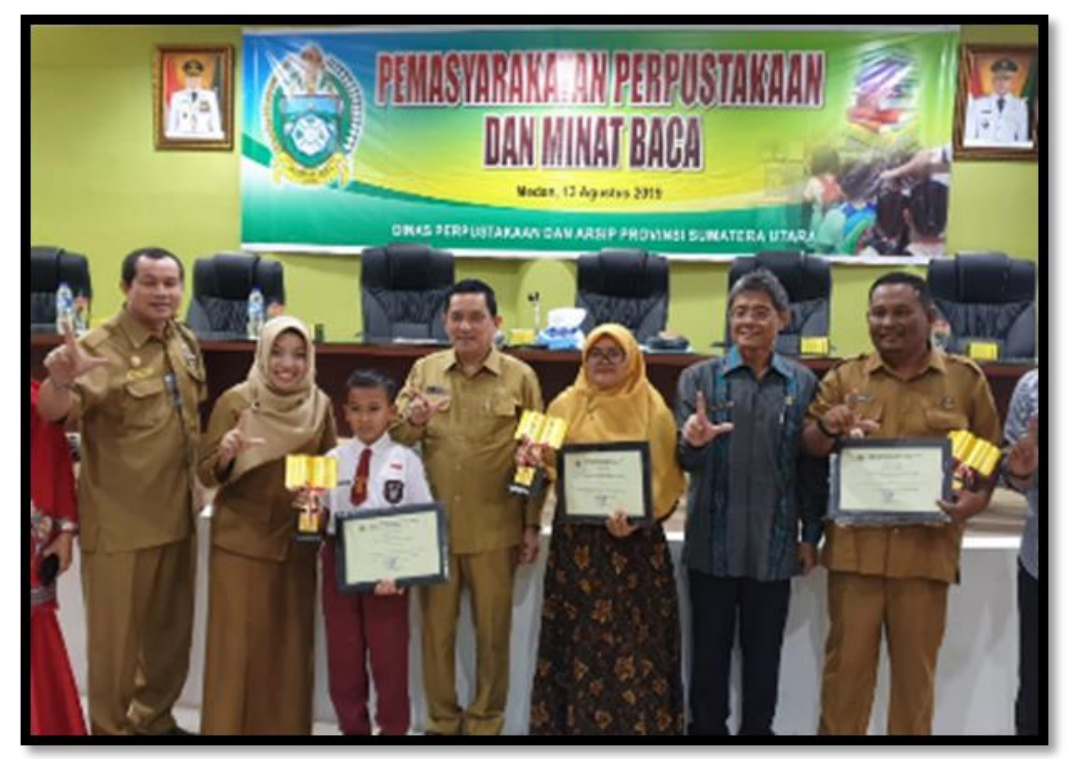

Gambar 14. Perpustakaan Desa Kolam-Padepokan Iqro menerima Piala juara 1 sebagai Perpustakaan Desa Terbaik tahun 2019 dari Kepala Dinas Perpustakaan dan Arsip Prov.Sumatera Utara.
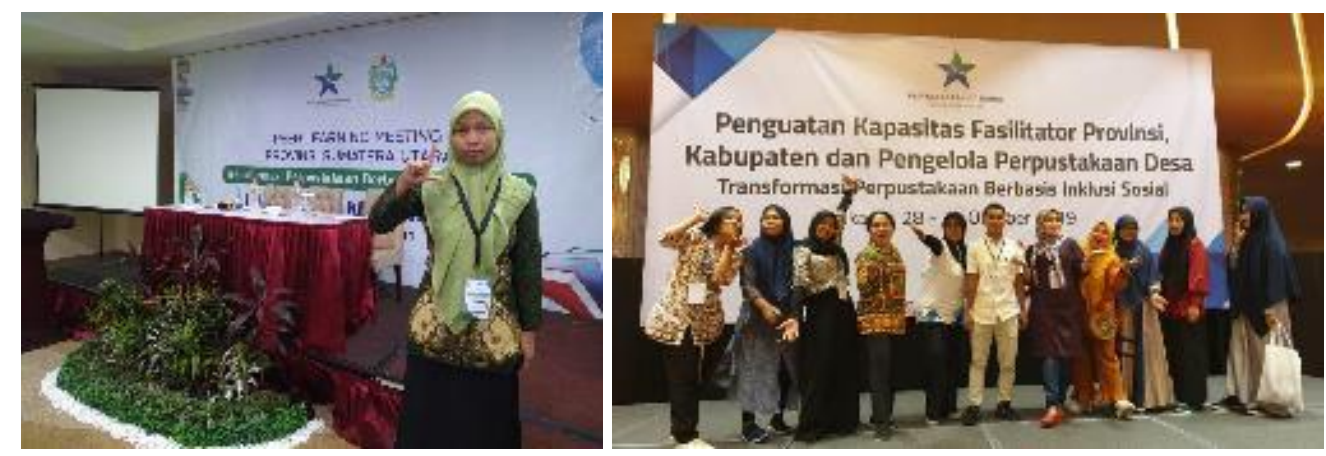

Gambar 15. Pengelola Perpustakaan Desa Kolam Padepokan Iqro terlibat dalam berbagai pertemuan literasi. 

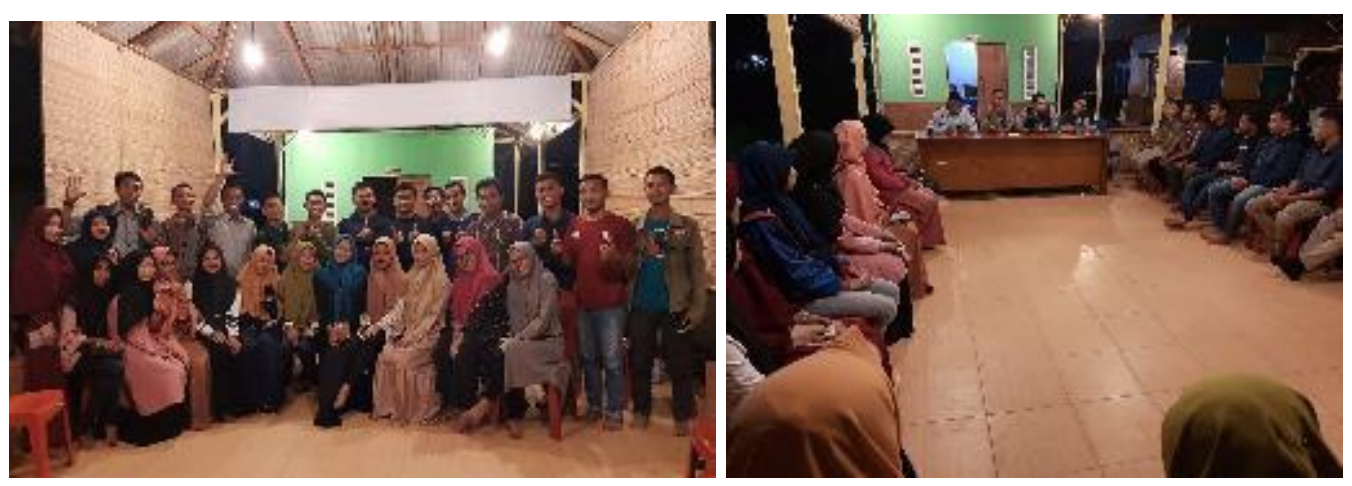

Gambar 16. Perpustakaan Desa Kolam Padepokan Iqro menjadi pusat kegiatan warga (seminar, diskusi pemuda, dll).

\section{SIMPULAN}

Pembangunan dan Pengembangan Sumberdaya manusia (SDM) di Desa Kolam bisa meningkat di masa depan. Program ini melanjutkan capaian program tahun 2017 dan 2018 yang lalu. Selama pelaksanaan PkM Nasional 2019 ini, berbagai kegiatan telah terlaksana, diantaranya adalah memberikan bantuan untuk renovasi ruang perpustakaan Desa Kolam, memberikan bantuan mobiler untuk perlengkapan perpustakaan Desa Kolam, dan memberikan bantuan rak-rak buku, membangun media informasi dan kampanye literasi, memfasiltasi penerbitan buku kumpulan cerita anak, dan peluncuran Desa Kolam Sebagai Kampung Literasi. Pelaksanaan PkM Nasional UT Medan tahun 2019 Desa Kolam Kabupaten Deli Serdang ini membawa dampak yang sangat baik bagi waga Desa Kolam.

\section{DAFTAR PUSTAKA}

Barus, R.K.I., dan Ressi D., (2017), Literasi Internet pada Perempuan Desa, Jurnal Pendidikan Ilmu-Ilmu Sosial, 9 (1): 84-89.

Benazaria. (2018). Pengembangkan Literasi Digital pada Warga Negara Muda dalam Pembelajaran PPKn melalui Model VCT, Jurnal Pendidikan Ilmu-Ilmu Sosial, 10 (1): 11-20.

Rencana Pembangunan Jangka Menengah Desa Kolam. 2016-2020

Setiawan, D., (2017). Pengembangan Model Kurikulum Berorientasi KKNI di Fakultas Ilmu Sosial Universitas Negeri Medan, Jurnal Pendidikan Ilmu-Ilmu Sosial, 9 (2): 112-120

Siregar, H., A. Suryanto, T. Rachmi, Minrohayati. (2016). Pedoman Program Abdimas Nasional UT. Peningkatan Kapasitas Dan Pemberdayaan Masyarakat Berbasis Desa Mitra. Universitas Terbuka.

Undang-Undang Republik Indonesia Nomor 6 Tahun 2016 Tentang Desa

Yakob. M \& Sari. M. (2019). Peningkatan kemampuan Siswa SMP Membaca Puisi Dengan Metode Pembelajaran Aktif Kreatif dan Menyenangkan. Journal of Education, Humaniora and Social Sciences (JEHSS). 2 (1):93 - 103. 